\title{
Music and Society in Late Colonial India: A Study of Esraj in Gaya TIRTHANKAR ROY
}

In the late nineteenth and early twentieth centuries, Indian classical music was in transition. Most readings of the transition stress the choices of the professional musicians, as these musicians and the institutions in which they functioned were caught up in political and economic movements such as nationalism and commercialization. This article studies a different type of transition: when a small-town professional group with a strong associational culture became musicians. This second process, standing in contrast to the received narratives, suggests novel lessons in the history of urban cultures during a time of change.

Keywords: colonial India, esraj, Gaya, Gayawals, gharanas, harmonium, Indian classical music, nationalism, urban culture

Tirthankar Roy (t.roy@1se.ac.uk) is Professor of Economic History at the London School of Economics and Political Science. 


\section{INTRODUCTION}

Tradition was invented in Calcutta city.

- Manoharlal Dheri ${ }^{1}$

The historiography of Indian classical music, both the northern or Hindustani and the southern or Carnatic varieties, accepts that between the mid-nineteenth and the mid-twentieth centuries, a deep change occurred in the context in which music was performed, produced, consumed, and learned, that this change influenced the styles and the repertoire, and that the modern version of "classical" music emerged from this turmoil. This paper rethinks the emergence of music in its modern form with one significant and underexplored case study, Gaya town in eastern India, and suggests that the paradigms commonly used to understand this transition need revision.

The process is usually studied via two paradigms of transition. Common to both paradigms is the idea that before the nineteenth century professional musicians were maintained by temples and courts, whereas from the second half of the nineteenth century onward, the extent of patronage narrowed, the patrons were poorer than before, and musicians traveled far to seek a new market for their arts. They found it in the rising middle class in the port cities, Bombay, Calcutta, and Madras. This encounter gave rise to a new generation of musicians whose predecessors were not musicians, encouraged the formation of music schools and public concerts, and reduced barriers to enjoyment and learning. In other words, music became a popular commercial art. From this common root, historiography takes two different roads.

One of these emphasizes relatively more the old world of the professional musician. I will call this the gharana-in-transition model. "Gharana" is used as a shorthand to describe the old world of music in northern India, mainly because musicians themselves have often used the term to explain who they were and how they needed to change. The word loosely refers to a vertically aligned collective of masters and apprentices, where seniority within the collective entailed knowledge and power. Phrases like the "traditional paradigm of transmission" of music and "the decline of the gharana system" hint at the changed situation 
of the professional musician in the new world (Hamilton 1994; Kippen 1988; Neuman 1980; Scott 1997; Van Der Meer 1980). Whereas courtly patronage and hereditary, family-bound learning had encouraged the development of virtuosity and the emergence of distinct styles, musicians confronting less demanding and less knowledgeable consumers relaxed standards. ${ }^{2}$ Commercialization of music weakened the authority of the seniors and their ability to claim a property right to complex forms of knowledge. Some of that knowledge disappeared (Roy 1998).

The geographical context to which this story applies with force is a small area in the western part of the Indo-Gangetic plains, where centuries of Indo-Islamic sponsorship of complex arts had left a legacy of well-developed master-apprenticeship. Both music and these crafts recruited apprentices from neighborhood and kinship networks. And both had to adapt to exit, emigration, and the creation of new markets. Some of Hindustani music's oldest masters and their gharanas emerged from towns in this region.

In the second story, which I call invention-of-tradition, music became an ingredient in the redefinition of the elite, upper-caste, and national identity. The emerging middle class in the port city discovered music, coded its grammar and repertoire, gave it structure, and wrote its history. Music became classical and literate in the process and distanced itself from folk and popular counterparts, which became timeless and preliterate. In Madras, classical music became connected with the redefinition of Tamil Brahmanic identity (Ram 2011; Subramanian 2017). For some nationalists, classical music signified a precolonial heritage unsullied by Westernization (Bakhle 2005; Subramanian 2011, 2017; Weidman 2006). ${ }^{3}$ In Calcutta, the Indo-European cultural encounter encouraged writers and publicists to rehabilitate classic music in Indian culture (Capwell 1986). If the geographical context of the gharana-in-transition was the craft town of northern India, the invention-of-tradition happened in the port city.

As I will show, not all towns and musician collectives that shaped the emergence of modern classical music fit these paradigms, and we need to add other ingredients to the story. The town this paper will discuss is Gaya, and the collective the Gayawals or the Hindu priests of Gaya. A part of this social set acquired a reputation in music between 1900 and the 1960s. The reputation endured long after the masters who built it had passed. In current lists of gharana-bound musicians, the term applies indiscriminately to any collective of musicians. Thus, Gaya is now known as the Gaya gharana. But Gayawals were not a hierarchical body of masters and apprentices, as the North Indian gharanas were. They did not have direct or 
indirect links with the North Indian gharanas. Nor did the Gaya musicians see themselves as the bearers of a political ideal or an elite identity. Instead, their reputation stemmed mainly from an extraordinary innovation, which was to popularize two hybrid instruments in the concert hall. I suggest that this example contributes to four arguments that expand the narrative of the emergence of classical music.

First, if migration and circulation of masters from the old world appear as a disruption of some sort in gharana-in-transition, migration and circulation have the opposite meaning in Gaya's history. A center of pilgrimage, Gaya was situated in a network of circulation of people. In the late nineteenth century, the circulation became more frequent and brought Gaya's priests in contact with the wealthy households of the port city. In the port city, the musical tradition was being remade. Talented and offbeat musicians could hope to find a receptive audience there. The small-town social set was aware of this (see the quote at the head of the article). The exchange that followed strengthened Gaya's reputation and its attraction to musicians outside the town. Whereas gharana connotes "strong ties" among people, Gaya's efflorescence displays "the strength of weak ties" among musically connected people. ${ }^{4}$

Second, Gaya allows us to rethink musical collectives. In the years when mass media and institutional music instruction were limited, cooperative collectives that formed around masters, students, and consumers sustained music teaching, performance, and discourse. The gharana was such a collective. Whereas the gharana was formed of organic and vertical ties based on kinship and family, in Gaya we see the emergence of democratic and synthetic collectives that developed around a common purpose. ${ }^{5}$ This coming together did have prehistory, however. Descriptions of Gayawals during the time in question reported the existence of a strong associational culture. ${ }^{6}$ The culture mattered, though the agency of individuals mattered as much if not more.

Third, Gaya has lessons about the temple towns of northern and eastern India. Towns that had a significant circulation of wealthy pilgrims, such as Benares and Mathura, also saw a musical efflorescence of some kind. The anthropological scholarship on temple priests tends to underestimate this creative energy. In Gaya's case, scholarship conforms too much to the unfavorable opinion often expressed by the pilgrims (discussed in the next section). Gayawals commanded particularly low esteem among those who used their religious services. By writing about the music connection, my aim is not to restore the Gayawals' 
reputation as religious intermediaries, but to suggest that their economic situation and wide exposure made some of them suitable candidates to explore new cultural frontiers.

My final, larger point relates to innovation. Neither the gharana-in-transition nor inventionof-tradition offers a clear definition of what innovation might mean and where it came from during the time of transition. The former tends to be pessimistic about the quality of the music, implying that the decline of the gharana entailed the loss of a purer tradition. The latter model does not permit us to compare the premodern and the modern music based on their intrinsic quality. My example is clearer on the point. Gaya was extraordinarily innovative. Its innovation consisted of the adoption of two instruments (esraj and harmonium) that had no link with the music's Indo-Islamic heritage, and their elevation as instruments for classical music performance. Gaya's musicians led this process. They could do so because they did not emerge from a preexisting institution of learning and did not need to use the gharana trope to justify their choices, as professionals often did. The instruments did not stem from the gharana system either. Therefore, esraj plays an important part in my story; more on this later.

The following three sections discuss the context, three key figures in Gaya's emergence, and the maturation of their legacy in the mid-twentieth century. I return to the lessons of the study in the concluding section.

\section{The ConTeXt: GayaWals AND MuSiC}

Gaya is a town of half a million people in the southern part of Bihar state in eastern India (see figure 1). Gaya's fame owes to religion. The oldest part of the town, known as Andar Gaya or Inner Gaya, developed around a Vaishnav temple known as Vishnupad, the holiest site for the conduct of rites that enable a departed soul to be released from the cycle of birth and rebirth (pind-daan, see O'Malley 1906). Gaya had an association with characters from the Ramayana, but the present temple was built towards the end of the eighteenth century. Bodh Gaya, where Buddha attained enlightenment, is located seven miles away. Buddhist kings, such as the eighth century CE Pala king Dharmapala, sponsored seminaries, monasteries, and temples in this area. The town is surrounded by low, isolated hills, which were homes to ascetic orders. 


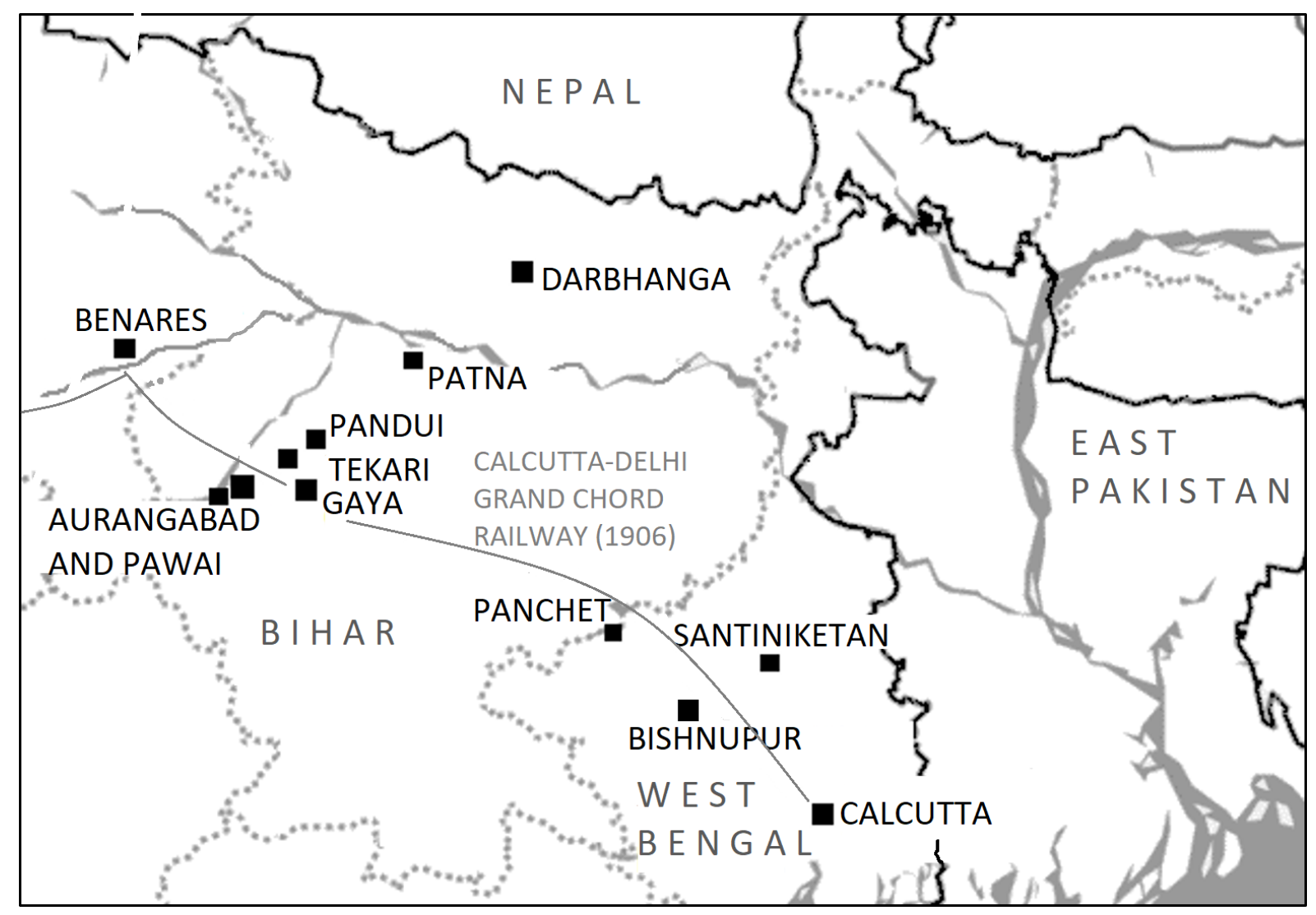

Figure 1. Map of Gaya and eastern India, 1950.

Although the religious sites had been present for centuries, Gaya as a city was built more recently. The modern history of the city can be traced back to the turn of the eighteenth century, when the Mughal king Aurangzeb or Alamgir declared a part of the present territory of the town as a taxable estate, or jagir, known as Alamgirpur. The holder of the jagir became locally known as Chaudhary. The emergence of basic administration and the settlement of a small contingent of Pathan soldiers made the town larger than before.

The foundation for Gaya's religion-based urbanism was laid in the eighteenth century. In the late eighteenth century, the independence, prosperity, and ambitions of the post-Mughal successor states led to the construction of a series of seminaries, schools, bathing ghats, and temples in Gaya (and Benares). The present structure of the Vishnupad temple owed to the benefaction of the Maratha queen Ahilya Bai Holkar (Prior 1990, on Gaya's Maratha connection). Several other temples in the town also date to the eighteenth century. From this time on, the town was no longer significant as an administrative center. It was more significant as a town in the service of religion. Still, the sustenance of that identity would have needed a sounder economic base. This base took shape in the nineteenth century. 
By the end of the nineteenth century, Andar Gaya had acquired the character that it now has, a dense settlement of family homes of Hindu priests, pandas or Gayawals, interspersed with dormitories owned by panda family firms. The core area is known as Char Phatak, or fourgates, and is almost entirely populated by pandas. The oldest homes, situated on a hillside known as Upardih next to the temple, date back to the eighteenth and nineteenth centuries (see figure 2). Those nearer the foothills are more modern.

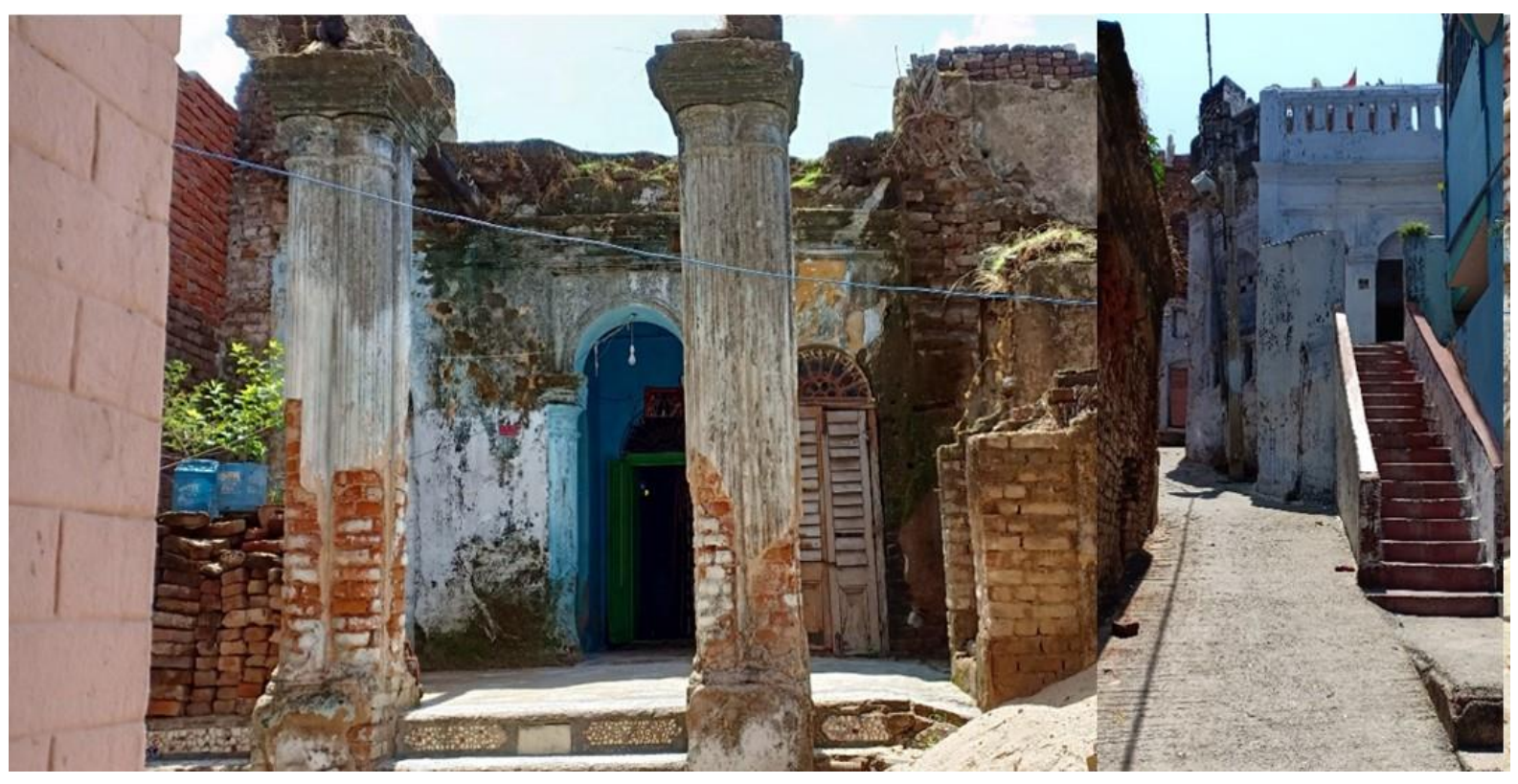

Figure 2. Two views of Upardih in Andar Gaya, June 2018. Photograph by the author.

Who were the pandas? A panda is a priest hired to perform rituals in a specific temple site. It was always possible to arrive at a temple town and hire a panda on the spot. However, a wealthy Hindu family tended to hire one panda to perform all rituals. Besides, there was a convention that once one panda performed the pind-daan ritual for a family, all future pinddaans for that family had to be conducted by the same panda. Pandas engaged by a rich family were not individuals, but firms bearing family names, within which priesthood passed on from father to sons. The partnership with a client (jajman) survived generations if the client family was large and rich, and the panda family was trusted and respected within panda society. Such lasting partnerships depended on the status of the panda within the community. As in any other business, the status derived from the wealth and power of the clients of the firm. Significantly, it also depended on the reputation of the founder as a Sanskrit scholar, the hereditary priesthood of a local temple, and cultural accomplishments. 
When a partnership like this survived, the panda firm could choose to keep a limited portfolio of rich clients, and thus devote more time per client or to itself. The client would reward such exclusive service with land grants and cash rewards. Some of that money was invested in the construction of dormitories (dharmshala) for pilgrims. Until the 1970s, panda-managed and owned dharmshalas were the only places where an outsider could stay the night in Andar Gaya. A few minutes after stepping out of the train from Calcutta, a visitor would have chosen a whole package of services, consisting of a priest to perform rites, a place to stay, and sanctioned food.

Gaya was relatively well connected with the eastern and the western extensions of the Gangetic plains through the Grand Trunk Road. There is little doubt, however, that with the 1906 opening of the Grand Chord section of the Calcutta-Delhi railway, in which Gaya was a prominent station, pilgrim inflow increased. Estimates of the number of pilgrims vary widely and are never reliable. Still, some measure of Gaya's prosperity in the early twentieth century can be gauged by the fact that in 1906, Gaya received 300,000 pilgrims. About 200 to 300 Gayawal families served their welfare, then. If the number of pilgrims increased with population, the number would have almost doubled by 1940. So did the number of Gayawal families, reaching 500 in 1952 . With competition for their services being as keen as these numbers suggest, it is no wonder that an observer noted in 1952 that "Gayawals are either rich or middle class. Seldom is a Gayawal poor" (Prasad 1952, 281).

Still, in cultural terms, the richest Gayawals began to form a distinct section of society. "An average Gayawal," in 1952, was "not educated. He [knew] his vernacular and may have [had] a working knowledge of Sanskrit," but had little more capital than that (Prasad 1952, 281). Consequently, he struggled to recruit clients and often resorted to devious means to do so. But "the gulf between rich and poor Gayawals [was] widening." For example, "some of the Gayawals [were] the richest landlords in the locality. Some of them also possess[ed] large quantities of jewelry, since jewels and gold ornaments [were] given to them by the rich Hindu rajas and maharajas" (Prasad 1952, 281-82). They did not have to compete for clients and occupied the prime real estate of Andar Gaya. It is claimed by senior pandas today that in no other Hindu temple town had the temple priests acquired so much real estate as did the pandas of Gaya. This type of claim is difficult to verify. Comparisons aside, it is true that a sizeable number of panda families owned, and still own, dharmshalas, built temples and bathing ghats, spent on and managed seminaries, and left large sums of money in trust for the upkeep of temples. ${ }^{7}$ 
I believe that this elite part of Gayawal society was a nineteenth-century creation. The nineteenth century witnessed the emergence of a larger number of lucrative partnerships between pandas and rich clients. One source of this surge was the overlap between panda business and the system of land rights known as zamindari that the British created in eastern India. Rather like the Mughal rulers, the East India Company officers, who had come into possession of the region in 1765, preferred to negotiate a taxation arrangement with the existing village landlords, wherein the landlords (or zamindars) would pay taxes and in return enjoy rights to the produce of the land. Whereas the Mughal right was in principle a right to use land and nonhereditary, the British converted it into an alienable and hereditary proprietary right in 1793 . For several decades after this innovation, the zamindars were in a shaky position because the initial tax rate had been set too high. However, the tax amount was fixed forever, and agricultural commercialization increased profits from cultivation. In the second half of the nineteenth century, many landlords were secure enough to seek to enhance their prestige via cultural sponsorship. Some owned townhouses and lived there. Those who continued to live in the village sometimes invited and settled artistes there. Although Gaya itself was no longer a zamindari estate in the ordinary sense, the town was building bridges with the large villages and landlord estates around it through religion and, increasingly, music. Estates (riyasats) that were significant from a musical point of view include Pawai, Pandui, and Tekari within 100 kilometers of the town and Darbhanga further away (see figure 1). These names will reappear in the next section.

Zamindars were joined by merchants, bankers, and the service elite of the port city, Calcutta. These people had made money in the Indo-European trade in opium, the interregional and international trade in grain, and the moneylending that financed these huge operations. Railborne and sea-borne commodity trade, the backbone of this system of accumulation, increased in volume more than twenty times between 1870 and 1940. A great deal of this growth in volume was due to the railways moving goods from the interior to the ports, and vice versa, and was in the hands of Indian merchants. They included the migrant merchantbankers from Rajputana, the Marwaris, who sponsored dharmshalas in all the major pilgrim towns of eastern India.

Those panda families who had the right credentials and who lived in the right period of history in the town became wealthy and emerged as the elite members of the community, a cut above the rank and file. They became a distinct class not only by establishing a steady intergenerational business with rich families and thus becoming rich landholders and 
capitalists themselves but also through their frequent connection with the world outside. They traveled more because their clients sometimes insisted that they perform rites at their homes. (Only a select clientele could make such requests to the top pandas.) These travels brought them in touch with the cosmopolitan milieu of the port city, indeed making some of them an integral part of it. They were not just richer, but culturally distinct from the rest of the community in the town. That distinctness started to take a musical turn in the nineteenth century.

The prosperity was short-lived. What happened after 1950 can only be described as a rapid fall. The number of pilgrims flowing into the city fell from several hundred thousand in 1950 to 80,000 in 1961 . The decrease was caused in part by the partition of Bengal in 1947, which reduced the number of Bengali Hindu families who could travel easily to Gaya and had connections with the town. With the abolition of zamindari in 1950 and the fragmentation of the estates, the lucrative partnerships between the pandas and the Bengali landed gentry began to grow scarce in the mid-twentieth century.

The main anthropological monographs on the Gayawal capture this time of decline. Of significance is the pioneering work of Lalita Prasad Vidyarthi (1961), The Sacred Complex in Hindu Gaya. Vidyarthi discussed the economic rise of the Gayawals in the nineteenth century and the fall after 1950. In his reading, the community became more luxury-loving, idle, insular, and conservative because of the easy money earned. They were ill-equipped to adapt to the shock. The fall happened at least partly because Gayawals had grown too conservative. Vidyarthi did acknowledge the inequality between the elite and the subaltern but did not think it important. From this time onward, scholars have had few charitable things to say about the community. Vidyarthi's tone was severely negative.

Later research echoes the same sentiment and confirms that "[t]he Gaya pandas, the Gayawals, stand in particularly low public repute. They have become a byword as far away as the south of India, and the name is said to be a synonym for 'cheat' in Tamil" (Sopher 2011, 69). Vidyarthi's own later work on pilgrim towns recognized that temple priests developed a particular fondness for classical music. This was said in relation to Benares (Vidyarthi, Jha, and Saraswati 1979, 121). Gaya was another example. But surely music complicates the received view of the Gayawals as an insular and culturally conservative group. 
The fact that Gayawals in the early twentieth century had seen an economic elite emerge among themselves provides one clue to the popularity of music. The other element in the story is their strong associational culture. In 1907, an ethnographic book noted that Gayawals spent a lot of their time in clubs, whereas the women in their families stayed at home, supervising the Maratha working-class women who cooked their food. Among the men, club culture was big, and the clubs were platforms for sports and popular entertainment, including sponsorship of dancing girls (Crooke 1907, 99). Wealth accumulation among a section of Gayawals made some of them eager to maintain distance from low forms of entertainment. But they did not give up on clubs, instead forming new ones. A distinct class of clubs started emerging around 1900. Members of these clubs found themselves more and not less outwardlooking because they needed to build bridges with new cultural movements outside and were better placed to do so.

The interviews and feedback that the author of Sacred Complex builds on show the great importance of clubs in acquiring higher status within the community. "Many Gayawals," writes Vidyarthi, "tried to raise their position by maintaining local clubs known as baithaka. They invited and maintained wrestlers, prostitutes, and musicians of repute to entertain visitors at these clubs and thus distinguish themselves among their neighbors and caste groups" (Vidyarthi 1961, 94). My respondents would object to the bracketing of high and low forms of entertainment in the same sentence. They insist that clubs had distinct sets of sponsors and clientele. More generally, Vidyarthi underplays or overlooks differentiation within Gayawal society, a tendency consistent with his description of their economic condition in the 1960s as "proletarianization." My reading is that differences were a fundamental feature of the business, and forms of cultural sponsorship made the society more different. The musicians saw themselves as a distinct set from those who spent "sleepless nights in 'nach-watching, pan-chewing, and ganja-smoking”" (L. S. S. O’Malley, cited in Vidyarthi 1961, 95).

In the early twentieth century, richer Gayawals included several individuals known for Sanskrit scholarship, had "some very good writers and poets among them, and they [were] most interested in classical Hindustani music" (Prasad 1952, 282). The efflorescence of music in the town occurred with no prehistory of a music-bound master-apprenticeship lineage in the town, nor did it leave a legacy of such a lineage. It was an expression instead of a mini-renaissance among the panda elite, which extended to and absorbed music, along with wrestling and literary pursuits. 
Biographies of individuals who made the Gayawals music-bound illustrate some of these propositions. This paper uses two sets of facts as evidence of the Gayawals' involvement in music. The first cluster relates to three turn-of-the-twentieth-century artistes who established Gaya's reputation as a music hub. Using their biographies, I want to stress the unconventionality of their profile: none emerged from an established master-student lineage or gharana nor created one; they chose two instruments, first esraj and then harmonium, which did not correspond to any known gharana; and their legacy was more inspirational than institutional or stylistic. The second cluster of evidence comes from Gaya town in the early twentieth century and shows what happened after the town's reputation was established. Standard histories of North Indian music acknowledge Gaya as a hub but lack detail on the people and the chronology. This part of the paper fills in the gap by showing two things: the morphing of Gaya from a temple town into a destination for some of the more innovative and offbeat musicians from western and northern India, and the students and associates that the three artistes left behind. So little can be recovered of musicians of subsequent generations that came up in this context that I cannot but conclude that few of these individuals excelled either as teachers or as performers. The former cluster of evidence shows the strength of the synthetic community, and the latter cluster shows its weakness and vulnerability.

\section{Three Key Agents in Gaya’s EMERgenCe}

The three individuals are close contemporaries Kanhaiyalal Dheri (c. 1850-95, see figure 3) and Hanumandas Singh (c. 1857-1940, see figure 6), as well as Chandrika Prasad Dubey (c. 1875-1965, see figure 4). All three artistes chose the esraj as their main instrument, at a time when the music world was not familiar with the instrument at all. 


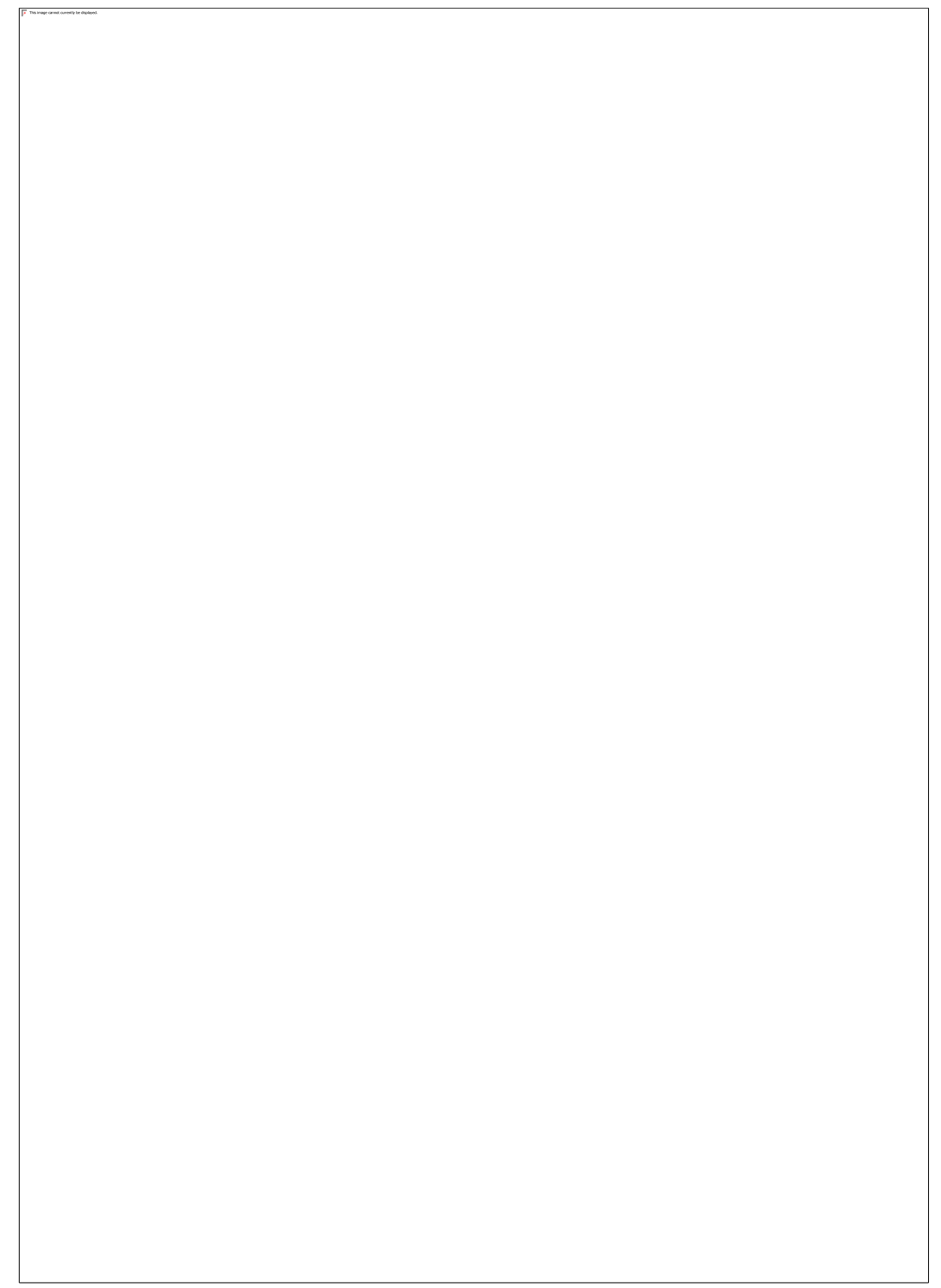

Figure 3. Kanhaiyalal Dheri. Image courtesy of Manoharlal Dheri. 


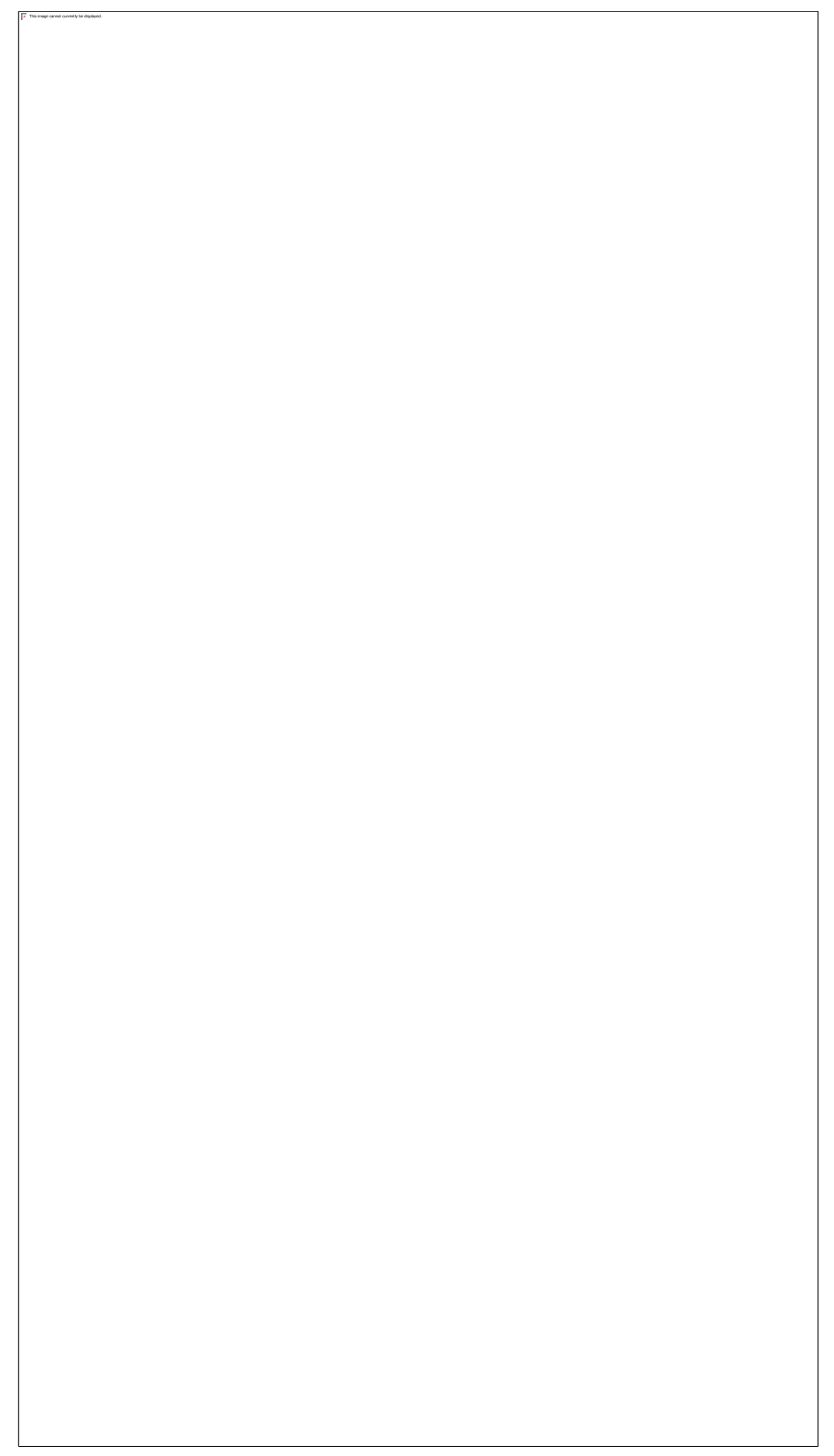

Figure 4. Chandrika Prasad Dubey (Roy Chowdhury 1929).

What is an esraj? The esraj was designed as a smaller version of the sitar meant to be played as a bowed instrument. The construction of a modern esraj is rather similar to that of a sitar, with one main string (in sitar called nayaki), two strings set to the tonic (juri), a fourth an octave lower (kharaj), and a set of sympathetic strings (taraf). Objects in museums and pictures in nineteenth-century reference books suggest that the conversion of older plucking instruments into bowed ones led to many experimental versions, of which several survive today (taus, dilruba, tarshehnai, and esraj). Reliable accounts of who invented these and when these were invented cannot be found. One fact is indisputable: they were created as instruments to accompany vocal music and emerged as solo concert instruments around 1900. 
This would almost always happen through the agency of exceptional performers. The three individuals I will discuss were significant in that way. ${ }^{8}$

Of the three, Dheri and Singh were brought up in the same household, that of a prominent Gayawal of that time, and the father of Kanhaiyalal, Ramhari Dheri. While so much is known, the order of precedence between these two musicians is disputed. I cannot settle this dispute but discuss it since it concerns the agency of the Gaya priest in the musical renaissance.

One account follows from statements of Bengali musicians who lived two generations after Kanhaiyalal and were indirectly a product of these artistes' influence in turn-of-the-century Calcutta. The authoritative source in this set is the music scholar (and esraj player) Bimalakanta Raychaudhuri. Raychaudhuri hailed from a landlord family of eastern Bengal, which was known for sponsorship of instrumental music, especially sitar and esraj. The written biographies of the original Gaya artistes followed Raychaudhuri's construction closely (Raychaudhuri 1965). ${ }^{9}$ In turn, Raychaudhuri was a student of Sheetal Chandra Mukhopadhyay (1880-1945) and would have received his version of the origin of esraj in Gaya from the latter. ${ }^{10}$ Mukhopadhyay was an esraj player and visited Gaya, though the mention in Raychaudhuri's books that Sheetal Chandra took lessons from Kanhaiyalal cannot be verified. Around 1895-1900, when Kanhaiyalal died, Sheetal Chandra was a very young man (Sangit Mahabharati 2011, 2:513). The second version follows my own interviews with present-day Gayawals, descendants of Kanhaiyalal, and a book published in Gaya by a leading Gayawal. As far as I can ascertain, these two narratives evolved in parallel, without one set of narrators finding it necessary to cross-check facts with the other. The derived Bengali sources state that Hanumandas Singh was older than Kanhaiyalal by twenty years and taught the latter esraj. Gayawal sources insist that Kanhaiyalal was older than Hanumandas and taught him esraj. Two older compendia of musicians $(1929,1957)$ report that Hanumandas was "an associate" and "fellow brother" of Kanhaiyalal. In partial confirmation of the second story, I place Kanhaiyalal's date of birth nearer $1850 .{ }^{11}$ All reports confirm that he died at the age of forty to forty-five, in the 1890s.

I refrain from selecting one of the two accounts because both rely on legend rather than facts, and the choice does not matter very much to the point of these biographies, which is that neither emerged from an established master-apprentice lineage. But the difference between the two accounts is illuminating for two reasons. First, it reveals scholars' and historians' need to settle precedence between masters and students, the result of a fixation with the 
hierarchical collective. Secondly, it probably shows the anxiety that Gayawals feel about an outsider appropriating the credit for the original innovation.

Kanhaiyalal was not a musician by profession. He was the inheritor of a leading panda firm. He had considerable land in Ghazipur and Andar Gaya. He performed rituals as well as played the esraj in his jajmans' homes. Indeed his influence as solo esraj player was great in the places where he went as a priest. His jajmans lived in several places, of which Ghazipur and Calcutta were probably the most important.

If we disregard the legends, he was a vocal musician who picked up esraj and taught himself the instrument. A house opposite the present mansion of the family in Upardih is said to be the place where Dheri practiced and held his own "sabha," another name for musical clubs. Little is known about the members of that sabha, except that a locally famous tabla player, Chaumukha Ustad, was one of them. Kanhaiyalal was an accomplished wrestler and maintained wrestlers. Jajmans gave him fees in money, which maintained his household, and gave him gifts in land and metals (in which was included a silver bed) that were tucked away in the treasury. ${ }^{12}$

Towards the end of his short life, Kanhaiyalal was India's best-known performer of esraj, and almost certainly the first public performer of this instrument. Public concerts as we know them now were then unknown. However, Calcutta city had many merchant and landlord homes where musicians performed before an invited audience. Kanhaiyalal traveled often and like a rais or aristocrat. When traveling, he went with a large entourage, including his munim or accountant, servants, and musical associates. To manage his affairs in Calcutta, and surely to participate in the music world of the city better, he purchased a house on Mahendra Goswami Lane in the Simla-Hedua area of north Calcutta, once home to rich Bengali merchants of Subarna Banik origin. This house was sold by Madhavlal and Manoharlal Dheri in 1964. When Kanhaiyalal died, his esraj was cremated with his body, and a memorial was erected in Babu Ghat on the Hooghly in Calcutta, though no remains of this monument seem to exist.

According to Gaya sources, during the Indian Mutiny (1857-58), a kheyal singer named Haralal or Haridas Singh came from the troubled Charkhari state in central India to Gaya with his young son and left him in the care of the panda Ramhari Dheri. The boy was called Kanhaiya. To avoid confusion, for Ramhari's own son was of the same name, he was 
renamed Hanumandas Singh. If this account is correct, Hanumandas was born shortly before 1857. ${ }^{13}$ He may have died around 1940.

"Having made a good stock of Kheyal songs," a 1929 biography tells us, "Hanumandas began to practice Esraj. He has distinguished himself in it and thereby gained a good deal of reputation among the musical public of India" (Roy Chowdhury 1929, 3). He did not travel very much to perform, but left a significant legacy within Gaya, as the esraj teacher of Chandrika Prasad Dubey, and an instructor to his son Sohni Singh, who "distinguished himself as one of the best Harmonium players of India" (Roy Chowdhury 1929, 3).

Hanumandas would have been at his peak in 1922 when the famous musician from western India, Vishnu Digambar Paluskar, visited Gaya as a pilgrim. Having heard Hanumandas in a performance, Paluskar expressed amazement that a maestro such as he was "shut up in a box" like Gaya (Boudhiya 1994, 160). A few years later, his son, the harmonium player Sohni Singh, died, and Hanumandas all but gave up music.

The third and youngest member of the esraj triad was Chandrika Prasad Dubey. He was born in 1875 in Pawai village, about 100 kilometers west of Gaya. Dubey was born in a family often called "Vrittiya" or professionals, a sect of Brahmins who practiced music (along with other skills) as a profession. He had knowledge of Sanskrit but was not a Gaya priest nor known to perform priestly duties. His family held land in Pawai, and he was given land in several other places. In the 1920s, Dubey was clearly the most famous son of this soil. He learned kheyal singing from Hanumandas Singh but, finding his voice not up to the task, started learning esraj. It is said that Dubey was mentored by both Kanhaiyalal and Hanumandas.

Thakurwadi in south Bihar refers to Bhumihar or Rajput landed estates. The fort in Pandui in Jehanabad is a Thakurwadi and is known as Thakur Narayan Singh's Qila. Here, sometime between 1920 and 1930, Chandrika Prasad Dubey lived as the court musician of the landlord Birkeshwar Prasad Narayan Singh. The house he then occupied is now the site of a high school. Dubey was well looked after and received gifts as well as free food, clothes, a horse, and an elephant. The scale of his upkeep was a measure of his reputation outside Pandui. Paradoxically, this reputation induced him to leave the life of a court musician in a village estate. Thereafter he is known to have traveled with some companions (among them was Awadh Bihari Pathak) to many places, including South India. He was, however, living in Pawai estate at the time of his death around 1965. 
When the literate connoisseurs of the cities started documenting the biographies of contemporary musicians and recording their music, they wrote about Dubey, describing him as the greatest living exponent of esraj. Around 1940, Kanhaiyalal was a legend, and Hanumandas was inaccessible. But Dubey was there and much written about. Frustratingly, little of this writing touched on his style and repertoire- how close or how distant these were from vocal music or other instrumental music, for example. Descriptions are driven by impressions of his virtuosity. One eyewitness account said that "the fingers of his left hand moved at astonishing speed on the esraj reeds" (Garg 1957, 445). One of my respondents who had seen him play remarked that the distinctness of his music rested on his use of the bow, or the right hand. In the words of another of my respondents, a singer sang a known song, but when Dubey played he created a song that no one had heard before. ${ }^{14}$ We have to live with these impressionist and not very useful statements.

Chandrika Prasad is remembered in Gaya as the Esraj-e-Hind. No one knows for sure who awarded him this honorific title and when. In any case, as far as one can see, he was the only holder of the title in music history. Rantideb Maitra, a music connoisseur and music collector in Calcutta, says that Dubey was recorded in the 1930s. The record seems now untraceable. Dubey appears to be the only esraj player from Gaya, indeed the only musician of the town spanning nearly a century from his birth to the 1970s, to have ever been recorded (Roy Chowdhury 1929). His ancestral home, Kushal Bhawan, stood at Pawai and still stands there, reportedly containing some of his esrajs inside it (see figure 5). This collection is inaccessible because the property is under a legal dispute. 


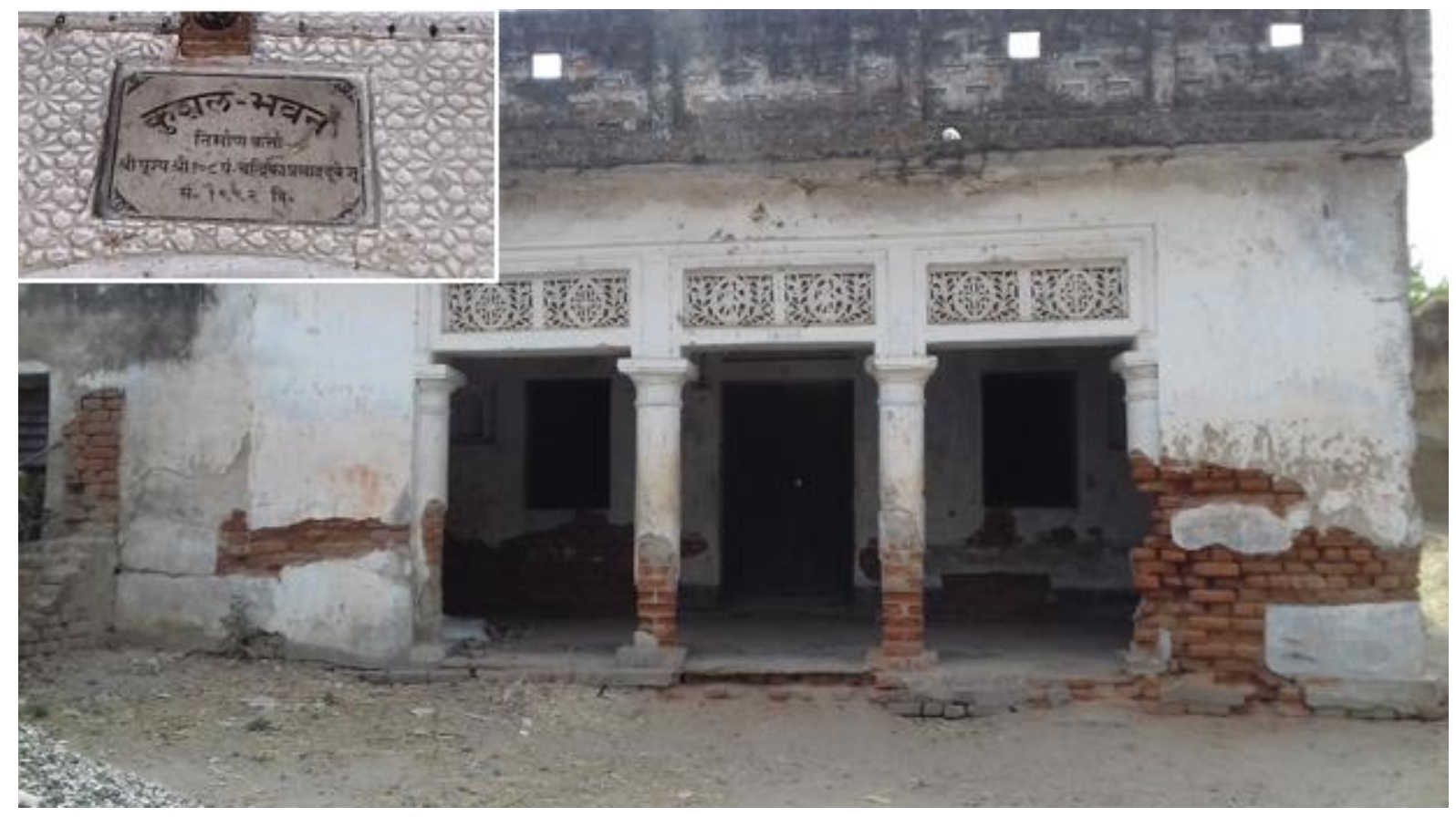

Figure 5. A portion of Dubey's home in Pawai. Inset: The plaque on the building that mentions his name. Images courtesy of Anubhav Kumar Dubey.

Why should we read about these artistes? The strongest collective legacy of these three musicians is esraj. Bowed instruments by and large originated as accompaniments and evolved into solo concert instruments during classical music's modernization. The pathbreaking contribution of the Gaya artistes was that all three of them were agents in this transformation. Nearly all esraj players in standard gharana lists directly or indirectly traced them to these individuals.

Kanhaiyalal Dheri was a familiar and popular figure in Calcutta of his time. On obscure authority, he is said to have influenced esraj playing in the family of Debendranath Tagore, father of the poet and composer Rabindranath Tagore (1861-1941), who had a significant effect on the popularity of esraj (discussed below), and that of Narendranath Datta, later Swami Vivekananda. He visited landlord estates located on the route between Gaya and Calcutta (see figure 1). One of these was Panchet, an old Mughal landed estate bordering the present West Bengal and Jharkhand states. The modern history of music in Panchet acknowledges Dheri as the reason for the presence of esraj among the musicians who live there now (Panchetgarh 2017). A gharana lineage prepared from Bengali sources lists several names as Dheri's students (Raychaudhuri 1965, 247). Of these, Sheetal Chandra 
Mukhopadhyay was a bridge figure who connected the artistry and innovation of Gaya with the popularity of esraj in Bengal.

There are now several solo classical esraj players. Excluding an esraj lineage of Delhi, which was originally a sarangi lineage, most esraj players today are connected with Bishnupur in Bengal. Bishnupur, a landed estate known for its sponsorship of terracotta temples and music, was originally the home of a dhrupad singing tradition. ${ }^{15}$ Esraj existed in Bishnupur in the nineteenth century but did not distinguish itself. An early nineteenth-century Bishnupur singer, Ramkesab Bhattacharya, was a frequent visitor to the merchant homes of north Calcutta and probably played the instrument (Bishnupur Gharana 2015). But the Bishnupur esraj had no particular claim to fame or stylistic distinction. It was not before five more generations of students that two Bishnupur artistes would establish esraj as a solo concert instrument. By then, the Gaya esraj players were well-known names in Bengal. It is certain that Gaya showed Bishnupur what was possible with the instrument.

Bishnupur's rise to fame owed to an accidental circumstance. In the mid-twentieth century, esraj received an endorsement from a powerful source. In 1930, the poet Tagore insisted that esraj should be the principal accompanying instrument for Rabindra Sangeet (in songs composed by Tagore) on All India Radio and that harmonium should be banished. The endorsement had a curious effect on the fate of esraj: it became more firmly identified with accompaniment. Nevertheless, after the move, esraj was introduced as a subject of study in Tagore's Santiniketan music school, and teachers came from Bishnupur. The two senior exponents, Asesh Chandra Bandopadhyay (1920-92) and Gaurhari Kabiraj (1913-1992), were both students of Ramprasanna Bandopadhyay, a vocalist of Bishnupur. Bishnupur's contribution to the instrument's later history was considerable, but Gaya was key to its emergence.

Unlike Dheri, Hanumandas Singh was not a panda and spent much of his time in Gaya town. He had a greater influence in promoting music in the town. A group photograph (see figure 6) suggests ways to understand the nature of this influence. The photograph was taken in the late 1920s. Most photographs of music groups in these times show either touring groups sponsored by wealthy patrons or a concert stage. This photograph does not belong in either class. It captures the spirit of what I call a "club," following Vidyarthi's usage. An assortment of incompatible instruments assembled together, with no hint of a hierarchy, the photo is meant to convey the sense of a democratic community rather than a hierarchy. 


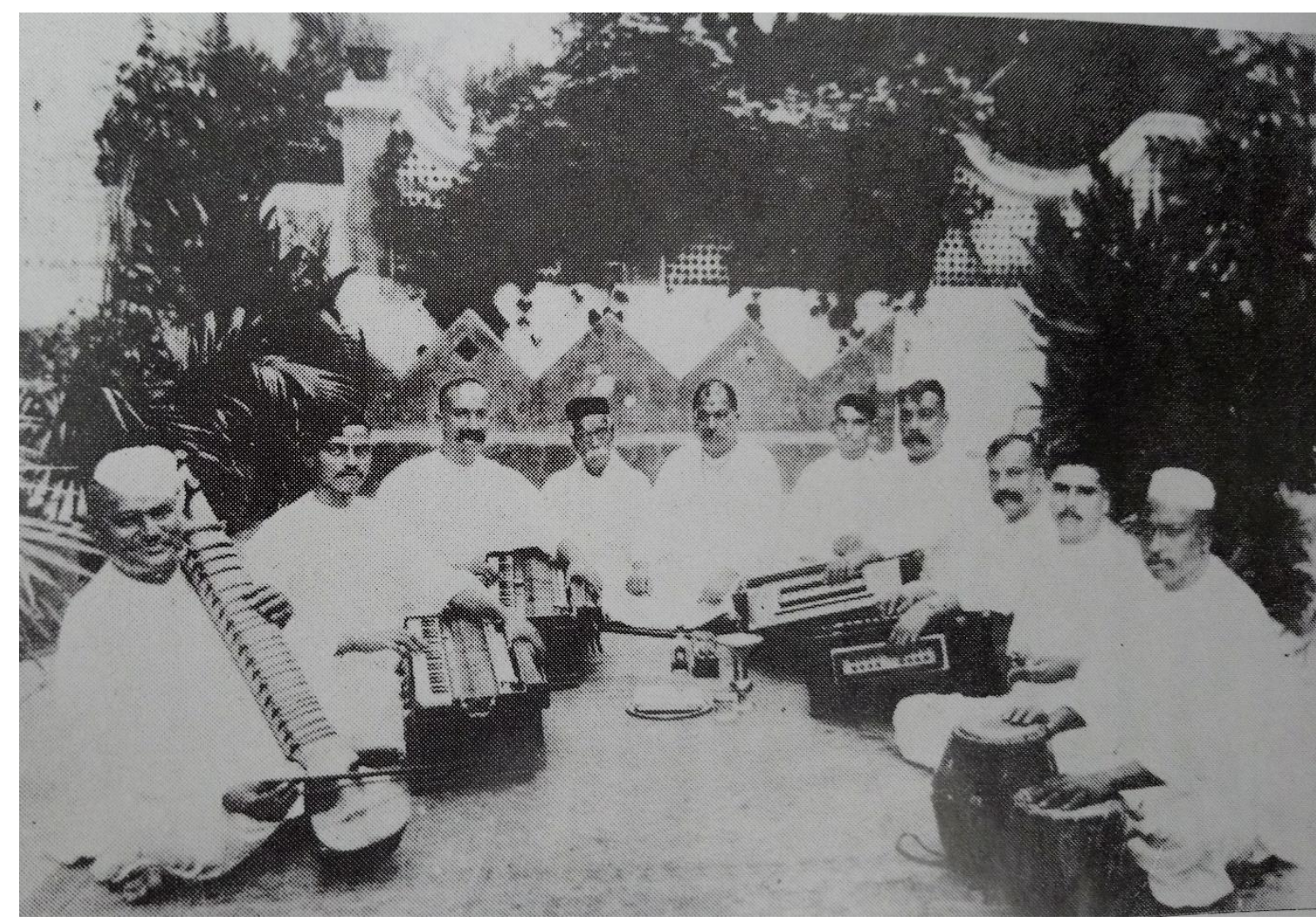

Figure 6. From left: Baiju Lal Pathak, Panna Lal Barik, Shankar Lal Parbatiya, Hanumandas Singh, Raja Ji Pathak, Shyam Lal Chaudhary, Sohni Singh, Narayan Lal Mishra, Gopal Lal Chaudhary, Mahabir Singh (Boudhiya 1994, facing page 160).

The status of esraj in the club is a curious one. The senior exponent Hanumandas Singh is seated in the middle of the group. The photo shows Baiju Lal Pathak, an esraj player, and probably Singh's student. Bullak Lal Bhikambhaiya was another contemporary esraj player; he was a member of the group but did not appear in the photo. Hanumandas had two other students, Tunnu Raut, and Somar Bhagat, who were known to perform esraj. Although their descendants still live in Andar Gaya, their connection with music seems to have ended. In short, esraj is present, but casually. We can infer that a part of Hanumandas's impact was in drawing semi-skilled musicians of varied interests within the set.

Hanumandas also inspired and imparted proficiency to a very small set of people. Dubey, who was not a member of this set of people, was mentioned. Besides Hanumandas, the most important member of the set was Hanumandas's son Sohni or Sohini Singh, seated with a harmonium in the photo in figure 6. Sohni Singh's choice of the harmonium was a curious 
one and will be discussed in the next section. He was a well-traveled and familiar figure in the All India concert scene. The obscurity of most figures shown in the photo suggests why Sohni Singh's early death would be heart-breaking for Hanumandas. It ended Gaya's promise to deliver an outstanding solo musician when such figures were scarce in the town's milieu. Gaya's reputation in esraj attracted Bengali musicians to this town. Mukhopadhyay has been mentioned. Another Bengali gentleman, Bhelu Babu (Jogendralal Gangopadhyay), an esraj player well known in Calcutta, relocated to Gaya around 1940 and made it his new home. His time there may have overlapped with the last years of Hanumandas's life. He was a homeopathic doctor by profession. For Bengali doctors to move to Bihar was not uncommon at all. But his choice of Gaya was influenced by the still-thriving esraj tradition there. He is remembered among the Gayawals today, but little more is known of his musical biography. Chandrika Prasad's legacy, rather like Dheri's, is inspirational. In the 1940s he was often invited to music conferences both as a solo artist and as an accompanist and received several honorary titles. These travels brought him in contact with younger musicians, one of whom (Bimalendu Mukherjee, 1930-97, sitar player of the Imdadkhani gharana) acknowledged Dubey's influence on his music. Among his students, two, Narhari Pathak and Siyaram Tiwari (1919-98), distinguished themselves as musicians, both as singers. Tiwari was one of the great names in dhrupad singing in the late twentieth century. He followed the Darbhanga dhrupad tradition and modified it considerably, making it more attractive and popular. He was also Dubey's son-in-law. Dubey's wife, Anandi Devi, came from Darbhanga, an enormous landlord estate in north Bihar commanding a territory of 2,500 square kilometers and known for its sponsorship of music. ${ }^{16}$

The masters of Gaya were solo players of an instrument that had been a minor medium of accompaniment a generation before. For the reputation they had built up as esraj players, it would have been beneath them to be accompanists and hazardous for singers to be accompanied by them. To cite Amarnath Boudhiya's book on Gaya: "nowhere else would esraj-players receive so much respect" (Boudhiya 1994, 159). This statement, though not quite verifiable, sounds true.

Together, the three artistes made esraj a familiar instrument in the musical landscape of northern India. The innovation worked because, I believe, the time was ripe for it. In the cities, classical music was a field of experiment. As music became a popular and commercial art from the turn of the twentieth century onward, the demand for choice, novelty, and variety 
increased. The spate of contemporary experimentation with instruments, to which many museum pieces bear witness, would suggest this. There was another reason for a hybrid instrument to succeed. Teachers of traditional instruments were in short supply around 1900. Learning sitar or rabab (ancestor to the more popular plucking instrument the sarod) from a pedigreed master would involve an investment in time, money, and patronage that only the wealthy landlords and merchants could afford. Learning vocal music and adapting the knowledge to play a hybrid instrument avoided this obstacle. Surely the prospect was attractive to members of the middle class, who would not normally be able to hire a North Indian master.

The three artistes no doubt made Gaya a hub. But as the town's reputation grew, it attracted musicians from the neighborhood and far away. In the process, forms and media diversified further. Esraj was a reconditioned indigenous instrument. Following the same pattern of innovation, several forms of adaptation of Western instruments appeared. The most important ones were harmonium and a little later the violin. In the early twentieth century, Gaya took a lead in popularizing harmonium too. Immigrant musicians in the town played an important role in this, mainly by strengthening the connection between harmonium and newly popular forms of vocal music.

\section{THE EFFLORESCENCE}

Around Gaya, traditional gharanas had formed of professional musicians. Darbhanga had a dhrupad singing gharana, whose members had connections with Gaya (see Dubey's biography above). The so-called Pathak gharana, named after the sitar player Balaram Pathak (1926-91), had connections with Ishwarpur village, ten miles to the west of the town. Several members of this family were connected to Gaya.

Tekari, a landlord estate ten miles to the northwest, was home to several generations of rabab players - the most famous names were Basat Ali Khan or Basit Khan (1787-1887), and his sons Ali Muhammad Khan (1824-1885) and Mohammad Ali Khan (1834-1927)—who traced their ancestry to the Mughal court singer Mian Tansen.

This heritage did not interact with the pandas, but it had a connection with esraj. The most famous of the three was Mahammad Ali Khan, who later in life taught esraj to at least one Bengali landlord. ${ }^{17}$ It is more than likely that the presence of esraj in this family was linked to the reputation of esraj in Gaya town. 
Migrants, by contrast, were not exponents of the instrument. When Hanumandas and Chandrika Prasad were still relatively young, and Gaya was becoming known as a music hub, the town received a few high-profile visitors. Probably the most influential was Ganpatrao (1852-1920), popularly known as Bhaiya Saheb Ganpatrao or in Gaya as Bhaiyaji. He was born of an alliance between a member of the Gwalior royal family (Scindia) and a locally famous dancer. He grew up with a good foundation in dance and music and influenced a style of thumri singing that combined the two and had its zenith in Lucknow (Banerjee 1986, 29). ${ }^{18}$ At the end of the nineteenth century, Ganpatrao was a very famous singer. His extensive following owed to his distinct style that combined folk and classical idioms. The style influenced and transformed thumri singing in Gwalior, Bundelkhand, and the courts of the United Provinces. His use of the harmonium as an accompanying instrument made an extraordinarily powerful impression on the audience. "Many of them [members of local courts] became disciples of Ganpat Rao Bhaiya to learn this new style of singing and playing over an instrument" (Gupta 1973).

Attracted by the town's music and the Marathi diaspora, Ganpatrao came to Gaya )Figure 7). There, Ganpatrao is credited with having popularized the simpler and portable hand-pump version of the reed organ known as the harmonium. A near-contemporary instrument maker in Calcutta, Dwarakanath Ghosh, is said to be the inventor of the portable harmonium, which replaced a cumbersome foot-pedal version (Deva 1981). ${ }^{19}$ Whether or not he had the copyright, Ganpatrao was quite clearly the most influential player of the portable harmonium, one who influenced many, and he adapted the style of playing to the thumris that he performed. The dates and duration of his stay in Gaya are not known for sure, but it may have been in the early 1900s when he was an established singer. The legacy of the stay was twofold: the introduction of thumri singing, which remains a living tradition in Gaya though performed only by a handful of masters, and the introduction of the solo harmonium, which, like esraj, flourished in the early twentieth century. ${ }^{20}$ 


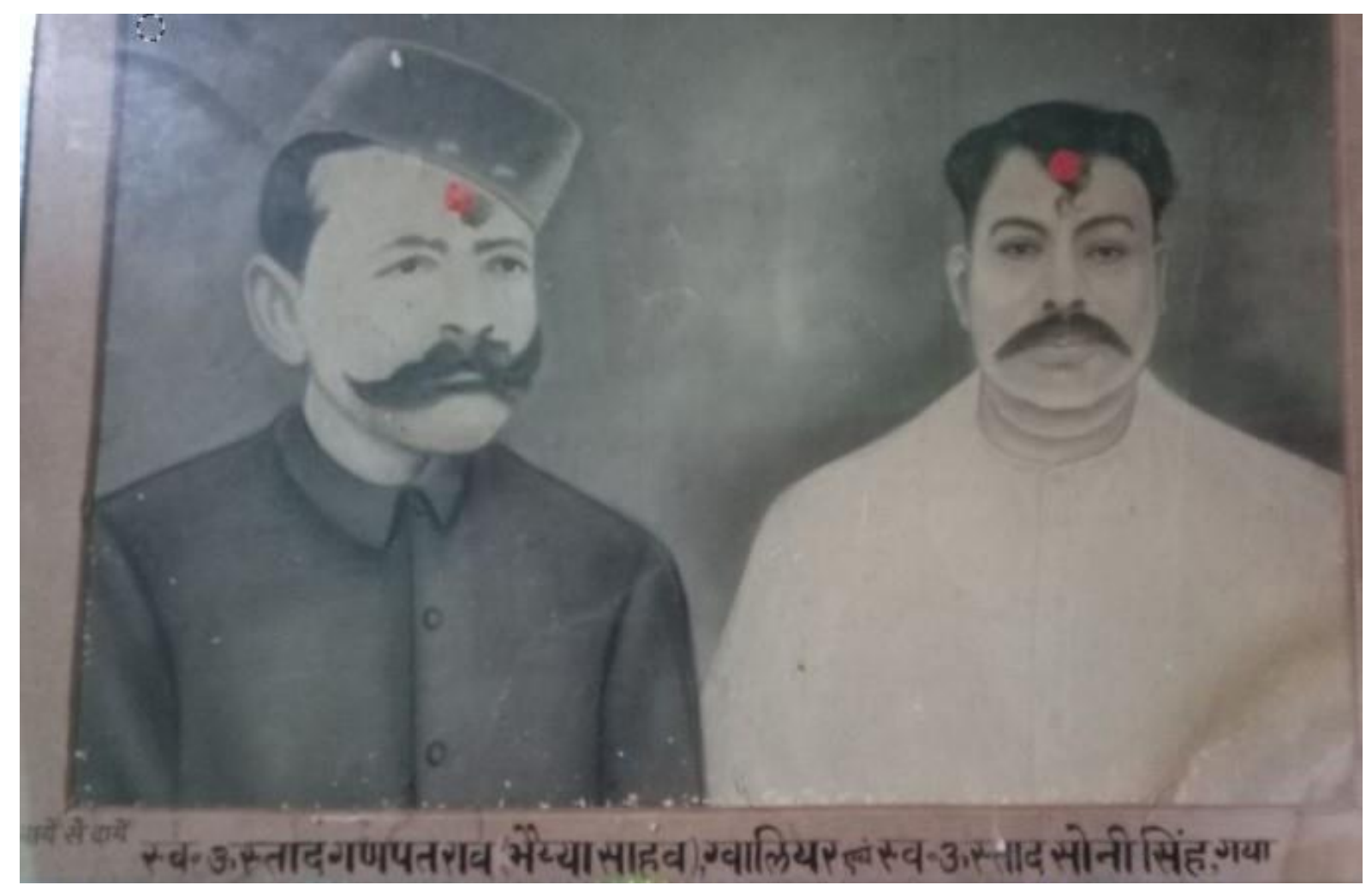

Figure 7. Ganpatrao and Sohni Singh. Image courtesy of Amar Nath Boudhiya.

Another visitor to Gaya around this time was Moujuddin Khan (1875-1926), again a significant influence on thumri singing in the town. Khan, or Moujuddin as he was popularly known, belonged to a Punjabi musical family that had shifted residence from Patiala to Benares early in the second half of the nineteenth century. Moujuddin's training was in the Punjabi style of kheyal singing but, advised by his friend Jagdip Misra in Benares, he took up thumri. Patronized by the merchants of Benares and Calcutta, Moujuddin became a professional thumri singer. He is now regarded as possibly the most important name behind the emergence of thumri as a modern genre. Again, the details of his visit to Gaya are unknown but likely occurred at the turn of the twentieth century.

Thus, Ganpatrao and Moujuddin, the two "best exponents of thumri in the early part of this [the twentieth] century," had both established links with Gaya (Bose 1970, 31). They had great influence on thumri singers elsewhere, but more as mentors and performers than as teachers. In Rampur, where Ganpatrao was a court musician, and Calcutta, where both spent considerable time, they are regarded as influences rather than as teachers. ${ }^{21}$ In Gaya too, individuals who came in close contact with them did not become musicians by profession; they remained pandas but took a serious interest in what the two did. ${ }^{22}$ 
According to several of my interviewees, the popularity of harmonium after Ganpatrao's visit to the town caused the gradual disappearance of esraj. The leading musician of Gaya, Rajendra Sijuar, explains that harmonium was easier to learn than esraj. There is another account of the rise of the harmonium in the town. "Thumris," according to a general history of the genre, "were mostly sung to the accompaniment of the harmonium of which Bhaiyasahib Ganpat Rao of Gwalior, Sohniji Maharaj of Gaya and Raja Nawab Ali of Lucknow were the best exponents" (Bose 1970, 31). We now see three strands coming together-Ganpatrao's stay, the popularity of thumri, and that of the harmonium in Gaya. Hanumandas's son, Sohni Singh, or Sohniji Maharaj in the statement above, embodied the connection (Figure 8). Sohni Singh did not learn harmonium from any master. He just started playing the instrument and, with an acute ability to copy tunes once heard, developed his repertoire. He was a young man when Ganpatrao lived in the town. Ganpatrao was told about Sohni Singh's ability and made sure that Singh was not within earshot when he played compositions that were part of the Gwalior repertoire. Apparently, it did happen on some occasions that after a performance by Ganpatrao where Singh was present, the next day the latter would play the same compositions perfectly for Ganpatrao. Sohni Singh, however, was an innovator on the harmonium in his own right. "Intricately grained" was the phrase used by those who had heard him play (Boudhiya 1994, 162). Among these were the king of Nepal and the landlord of the Darbhanga estate, both major patrons of music. The Maharaja of Darbhanga became his student and offered him the court musician position, an offer that Singh declined because of his attachment to the community in Gaya. Singh also traveled to Benares, and the music connoisseurs of the town knew him and respected him.

Sohni Singh left five or six students, of whom three were especially well regarded. These were Shankar Lal Parbatiya, Pannalal Barik, and Shankar Lal's younger brother Narayan Lal Mishra (see figure 6). The descendant of the original jagirdar of Gaya, Govind Lal Nakphopha, who was the head of the estate in the 1940s, was an accomplished harmonium player and the fourth student of Singh. Through their presence, two different styles of harmonium playing evolved, one influenced by Bhaiya Saheb Ganpatrao and the other by Sohni Singh. Within the Gayawal club, the two did not become rivals. ${ }^{23}$

These two individuals, Parbatiya and Nakphopha, are significant in Gaya's history because they sponsored concerts and artistes and thereby eased Gaya's evolution into what it is today, a small center for thumri. Parbatiya hosted the Benares thumri singer Rasulan Bai for some time. Nakphopha was the benefactor of a music conference called Gangamahal. He invited 
the Benares singer Ramprasad Mishra to settle in Gaya. Ramprasad Mishra's legacy, in the shape of his son Govardhan Mishra (1941-) and his student Kameshwar Pathak (1927-2017), both accomplished thumri and tappa singers, reestablished the musical reputation of Gaya in recent years. Pathak performed regularly on All India Radio, and taught and mentored several students. $^{24}$

From the 1960s onward, few of the town's musicians enjoyed the reputation that attached to Singh or Dubey. Esraj and harmonium flourished elsewhere, but not here. A few accomplished thumri singers dispersed. One cannot help feeling that the club at its peak contained many who shared a love of music, but too few with proficiency and creativity. Gaya fell into obscurity. 


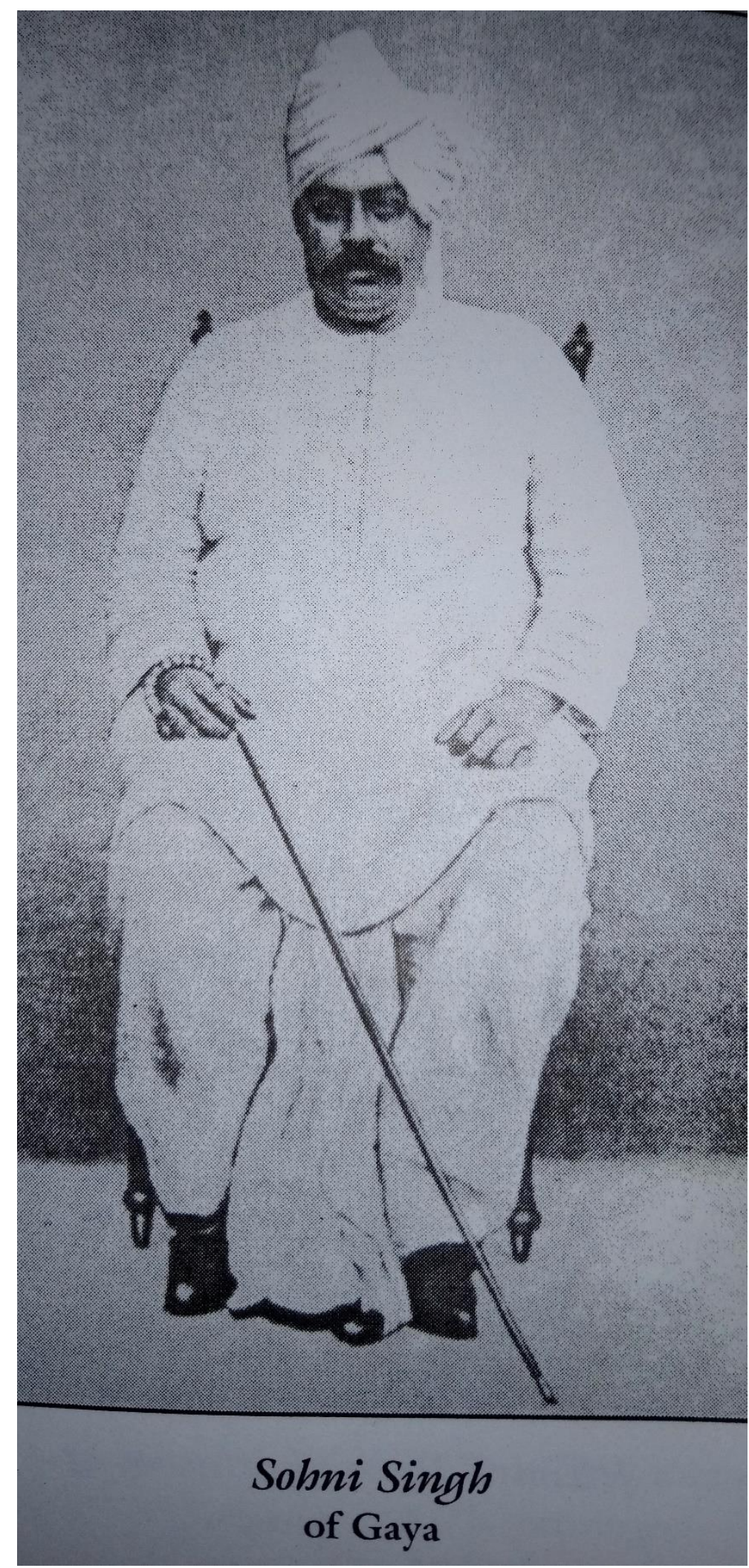

Figure 8. Sohni Singh. Image courtesy of Anubhav Kumar Dubey. 


\section{CONCLUSION}

The history of Gaya's music in the early-to-mid-twentieth century reveals forms of interaction between music and society that the standard paradigms of such interaction obscure from view. Unlike in the gharana-in-transition paradigm, communities of listeners and practitioners formed without there being a prior instructional lineage or stylistic heritage. Gaya shows some of the conditions for such an emergence: a group that circulated more, was professionally engaged with the wealthy music sponsors of the port cities, and one that possessed an associational culture.

In several ways, Gaya's musical efflorescence revises the received picture of the temple priests as conservative, insular, and occasionally amoral, living in a world of their own and refusing to change. This paper reveals much inequality and diversity among the Gayawals, and the presence of a core group that was dynamic, engaged, and innovative. Music befitted the panda elite club, and club culture spread it. Music did not follow standard rules, whether a master-apprentice lineage or any of the standard meanings of the word gharana. By not being burdened by gharanas and the sense of a heavy tradition to hold on to, the process took on a lighter, eclectic, and innovative aspect, of which the most significant expression was the popularity of esraj and harmonium, two instruments elevated from accompaniment to performance medium in their own right. In both cases, Gaya's artists played a leading role.

Gaya's music diversified in many directions after this foundation was laid. At the same time, the creative impulse weakened. Gaya lost economic momentum after 1950. A dearth of institutionalization and professionalization made music teaching lack stability. Whereas Gayawals still traveled a lot, Gaya was not a cosmopolitan town nor a progressive one. Unlike Calcutta or Madras, where musicians and music scholars actively engaged in nationalist politics, Gayawals were famous for indifference to all things political. ${ }^{25}$ Whereas in the big city, women moved on a significant scale into learning, teaching, and performance, in the making of Gaya's public culture, "women [were] not consulted at all, and they [did] not come out in public" (Prasad 1952). Gaya's music paid the same price for insularity and exclusion of women that several North Indian Muslim gharanas paid too-attrition and extinction.

\section{Acknowledgments}


I thank two referees and the editor of the journal for comments and suggestions that led to significant changes and improvements in this paper. Mrinmoyee Roy read an early version of the paper and made helpful suggestions. My greatest debts are owed to Prince Kumar and Shyam Sundar Kumar, who provided research assistance of the highest caliber. Doing fieldwork with them was rewarding and a pleasure. Finally, I thank the following persons in and around Gaya for their help and/or for agreeing to be interviewed: Amarnath Boudhiya, Sambhu Lal Bithhal, Manoharlal Dheri, Anubhav Kumar Dubey, Abhishek Kumar Dubey, Abodh Kumar, Pursottam Mishra, Rajeshwar Mishra, Baban Pathak, Rajendra Sijuar, and Chandrakant Prasad Singh.

\section{List of References}

BAKHLE, JANAKI. 2005. Two Men and Music: Nationalism in the Making of an Indian Classical Tradition. Delhi: Permanent Black.

BANERJEe, Projesh. 1986. Dance in Thumri. New Delhi: Abhinav Publications.

BISHNUPUR GHARANA. 2015. "Bishnupur Gharana." http://bishnupurgharana.com/site/user/history (accessed February 3, 2019).

Bose, SunIL K. 1970. “Thumri in Hindustani Music.” Journal of the Indian Musicological Society 1(1):29-32.

BoudhiYA, AmARnATH. 1994. Gaya darpan [Mirror of Gaya]. Gaya: Shree prachya vidya shodh sansthan.

CAPWell, Charles. 1986. "Musical Life in Nineteenth-Century Calcutta as a Component in the History of a Secondary Urban Center." Asian Music 18(1):139-63.

CROOKE, William. 1907. Natives of Northern India. London: Archibald Constable.

DeshPANDE, V. H. [1961] 1973. Indian Musical Traditions: An Aesthetic Study of the Gharanas in Hindustani Music. Translated by S. H. Deshpande. Bombay: Popular Prakashan.

DEVA, B. C. 1981. “The Harmonium and Indian Music.” Journal of the Indian Musicological Society 12(3):45-52.

GARG, LAKSHMI NARAYAN. 1957. Hamare sangeet ratna[The Jewels of our Music]. Hathras: Sangeet karyalaya. 
GranOVETTER, MARK. 1983. "The Strength of Weak Ties: A Network Theory Revisited." Sociological Theory 1:201-33.

GREIF, AVNER. 2006. Institutions and the Path to the Modern Economy: Lessons from Medieval Trade. Cambridge: Cambridge University Press.

Guha-Thakurta, TAPATI. 1992. The Making of a New 'Indian' Art: Artists, Aesthetics and Nationalism in Bengal, c. 1850-1920. Cambridge: Cambridge University Press.

GuPTA, B. L. 1973. “The Gwalior School of Music.” Journal of the Indian Musicological Society 4(1):5-15.

Hamilton, JAMES SADLER. 1994. Sitar Music in Calcutta: An Ethnomusicological Study. Delhi: Motilal banarasidas.

KIPPEN, JAMES. 1988. The Tabla of Lucknow: A Cultural Analysis of a Musical Tradition. Cambridge: Cambridge University Press.

McGowan, ABIGAIL. 2009. Crafting the Nation in Colonial India. Basingstoke, UK: Palgrave.

MORRIS, R. J. 1990. “Clubs, Societies and Associations.” In The Cambridge Social History of Britain, 1750-1950, Volume 3: Social Agencies and Institutions, ed. F. M. L. Thompson, 395-444. Cambridge: Cambridge University Press.

Neuman, Daniel M. 1980. The Life of Music in North India: The Organization of an Artistic Tradition. Detroit: Wayne State University Press.

O’Malley, L. S. S. 1906. Gaya (Bengal District Gazetteers). Calcutta: Secretariat Book Depot.

PANCHETGARH. 2017. "Music in Panchetgarh.” http://sgwebapps.co.in/panchetgarh/historyof-music-in-panchetgarh/ (accessed February 3, 2019).

Prasad, NARBADEShWAR. 1952. “The Gayawals of Bihar.” American Anthropologist 54:279-83.

PRIOR, KATHERINE. 1990. “The British Administration of Hinduism in North India, 17801900.” PhD diss., Cambridge University.

Rahaim, MAtT. 2011. "That Ban(e) of Indian Music: Hearing Politics in the Harmonium." Journal of Asian Studies 70(3):657-82. 
Ram, KalPanA. 2011. “Being 'Rasikas': The Affective Pleasures of Music and Dance Spectatorship and Nationhood in Indian Middle-Class Modernity." Journal of the Royal Anthropological Institute 17(s1):S159-75.

RAYCHAUDHURI, BIMALAKANTA. 1965. Bharatiya sangeetkosh.[Anthology of Indian Music] Calcutta: Imdadkhani School of Sitar.

ROY, TIRTHANKAR. 1998. "Music as Artisan Tradition.” Contributions to Indian Sociology $32(1): 21-42$.

Roy CHOWDHURY, HARENDRA KISHORE. 1929. The Musicians of India. Calcutta: Kuntaline Press.

SAngit MAHABHARATI. 2011. Oxford Encyclopaedia of the Music of India. 3 vols. New Delhi: Oxford University Press.

ScotT, Stan A. 1997. "Power and Delight: Vocal Training in North Indian Classical Music." $\mathrm{PhD}$ diss., Wesleyan University.

SoPHER, DAVID E. 2011. “The Message of Place in Hindu Pilgrimage.” In Holy Places and Pilgrimages: Essays on India, ed. Rana P. B. Singh, 57-80. New Delhi: Shubhi Publications. Subramanian, LAKSHMI. 2011. From the Tanjore Court to the Madras Music Academy: A Social History of Music in South India. 2nd ed. New Delhi: Oxford University Press.

- 2017. Veena Dhanammal: The Making of a Legend. 2nd ed. Abingdon, UK:

Routledge.

VAN DER MEER, WIM. 1980. Hindustani Music in the 20th Century. The Hague: Martinus Nijhoff.

Vidyarthi, Lalita PRASAD. 1961. The Sacred Complex in Hindu Gaya. New York: Asia Publishing House.

VidyARTHI, LALITA PraSAD, MAKHAN JHA, and BAIDYANATH SARASWATI. 1979. The Sacred Complex of Kashi: A Microcosm of Indian Civilization. New Delhi: Concept.

Weidman, Amanda J. 2006. Singing the Classical, Voicing the Modern: The Postcolonial Politics of Music in South India. Durham, N.C.: Duke University Press.

\footnotetext{
${ }^{1}$ Manoharlal Dheri is the great-great-grandson of nineteenth-century esraj maestro Kanhaiyalal Dheri. Interview in Gaya, June 2018.
} 
${ }^{2}$ This is not the place to discuss the extensive literature on the term. A precise definition is elusive, because it contains within it four distinct references: a family-lineage of learning and performance; a master-apprentice lineage not necessarily connected with family; a knowledge capital formed of style, genre, and repertoire that is passed on from older generations to younger ones; and a place of origin. Historians' use of it often consists of piling up attributes into a "sociomusical" compound. On gharanas as styles (gayakis), see Deshpande ([1961] 1973). On gharanas as a compound of attributes, see Neuman (1980): “[T]he structural core of a gharana is a lineage of hereditary musicians. What binds all such groups is style" (146, emphasis added). This approach of amalgamating attributes has been followed, with minor changes, in Kippen (1988) and Hamilton (1994).

${ }^{3}$ The almost parallel emergence of a discourse that saw the skilled crafts as the bearer of an Indian national tradition, and one under threat, is explored in McGowan (2009). See also Guha-Thakurta (1992) on the influence of nationalism on the emergence of a "high-art" culture in colonial Bengal.

${ }^{4}$ Strong ties like kinship and family are good at ensuring compliance and conformity of group members but are not good for innovation, whereas more novel ideas are exchanged in the presence of weak ties, when sets of people representing different experiences and backgrounds come in contact (Granovetter 1983).

${ }^{5}$ The duality between organic and synthetic overlaps with the distinction economists make between merchant guilds that function on the basis of informal ties and those that are based on formal rules (Greif 2006).

${ }^{6}$ I borrow the phrase "associational culture" from what seems to be its original use in explaining the growing complexity of civil society in eighteenth-century Britain to mean a group usually formed to serve a purpose and one distinct from family, neighborhood, and 
workgroup (Morris 1990). Purposive groups with informal entry rules, often working from socializing spots like taverns, figure in histories of political action in many countries.

${ }^{7}$ Madhavlal Dheri (born c. 1900), descendant of the esraj master Kanhaiyalal Dheri, was one of those who had left money in trust.

${ }^{8}$ Several other accompanying instruments emerged from the shadows and became solo concert instruments. The older and more indigenous bowed instrument the sarangi was one such example. The class of bowed instruments in which esraj belonged had little in common with sarangi in construction or in the context of practice and performance. Sarangi had many versions that were played with tribal and popular songs, especially in western India, before it was standardized to become a concert instrument. Esraj had a more elitist origin, emerging from milieus where sitar was already played. Violin and harmonium were adapted from Western music first as accompaniment and later as solo instruments.

${ }^{9}$ See also "Kanailal Dhendi (b. Gaya, c. 1861; d. Gaya, 1901)" and "Hanumandas Singh (b. Bundelkhand, Madhya Pradesh, c. 1840; d. Gaya, 1939)" in Sangit Mahabharati (2011, 1:513 and 1:408-9, respectively). Raychaudhuri was one of the advisers of the Encyclopaedia project.

${ }^{10}$ See "Sheetal Chandra Mukherji (b. Kirtibasa [now in Bangladesh], 7 May 1880; d. Kolkata, 14 Sept. 1945)” in Sangit Mahabharati (2011, 3:969).

${ }^{11}$ The oldest member of the Dheri family now is about seventy, and he is the great-greatgrandson of Kanhaiyalal. Calculating upward, his grandfather Madhavlal Dheri may have been born around 1900. This date seems plausible, because in his daughter's marriage procession (c. 1935-40?), the famous shehnai player of Benares, Bismillah Khan (19162006) played shehnai, and he was a young man then.

${ }^{12}$ Guard dogs protect some of the bigger and older panda homes. 
${ }^{13}$ At the end of the 1920 s, when a group photo of contemporary musicians was taken (see figure 6), he is seen sitting along with his son, Sohni Singh. Sohni Singh learned from Kanhaiyalal Dheri in his early life. Since Dheri died in the 1890s, and Singh himself died relatively young at about forty-five, soon after the photo was taken, his life could have spanned 1885 to 1930 . This makes the likely dates of Hanumandas c. 1857-1940/45. ${ }^{14}$ Chandrakant Prasad Singh.

${ }^{15}$ Dhrupad is thought to be the most ancient strand in classical vocal music of India. ${ }^{16}$ Among his sons, Mahendra Prasad Dubey played esraj and worked as manager in a colliery. Mahendra Prasad's younger son, Harendra Prasad, also played the instrument and was employed in the electricity department of Aurangabad town (next to Pawai). Esraj seemingly became extinct in the family after that. The grandson of Harendra Prasad, and an employee of the mail-order company Flipkart, owns the ancestral home now.

${ }^{17}$ He taught dhrupad to a few others, but rabab only to his son. With his son's premature death, the most distinguished classical rabab lineage ended, though $r a b a b$ continued in Afghanistan and Iran to serve a different musical genre.

${ }^{18}$ Thumri refers to a light and romantic song following the raga theme on which Indian music is based.

${ }^{19}$ Harmonium was not easily accepted as a suitable instrument for playing Indian classical music. On the thorny history of the harmonium, see Rahaim (2011), also a useful reference on Ganpatrao.

${ }^{20}$ A prominent landlord of the city, Madhav Lal Katriyar, was Ganpatrao's student and patron.

${ }^{21}$ There were a few exceptions, such as Badi Moti Bai of Benares, said to be taught by Moujuddin, and sarod player Hafiz Ali Khan, said to be taught by Ganpatrao. 
${ }^{22}$ Possibly the only professional musician in the Gaya set was the thumri singer Dhela Bai, who influenced musicians in the town, but little is known of her life.

${ }^{23}$ Among the next generation of students, Ramlal Boudhiya and Bishweshwar Lal Jhangar were trained by the Sohni Singh camp, but were more influenced by Ganpatrao's student Madhav Lal Katriyar's playing. Harmonium continued in these families for another generation, through Ramlal Boudhiya's son Bachhu Lal and Jhangar's son Munni Lal Jhangar (Boudhiya 1994, 163).

${ }^{24}$ Pathak's student, Rajendra Sijuar, is a well-known thumri singer in the Benares style and represents one of the few surviving links between classical music and the Gayawal heritage. Jai Ram Tiwari, another member of Sohni Singh's circle of musicians, also taught thumri to Sijuar. The Sijuar estate is part of a diversified business that owns hotels, both modern and traditional types. Chhotelal Sijuar, a landlord of Gaya, was honored with a CIE (Companion of the Indian Empire). He was a patron of wrestling and persuaded the great wrestler Gama Pehlwan to live in Gaya for a length of time. Sijuar's untimely death saw Gama depart from the town. I have been unable to ascertain the dates when Gama was in Gaya.

25 "In the successive national movements in India, not even one member of this community took part” (Prasad 1952). 